\title{
Studies in comparative sugar preference in rodents: II. Individual differences'
}

\author{
MAHLON W. WAGNER ${ }^{2}$, VALPARAISO UNIVERSITY, \\ Valparaiso, Indiana
}

The glucose vs fructose preferences of deer mice, Florida mice and kangaroo rats were examined. In addition to quantitative species differences in intake and in preference, there were individual differences such that some Ss preferred the sweeter sugar of the pair, some preferred glucose regardless of sweetness, and an occasional $S$ exhibited a spatial-position preference.

Sugars have commonly been used as incentives in studies of learning and motivation (Collier \& Myers, 1961; Marx \& Edwards, 1966; Young, 1966) under the assumption that sugars are universally acceptable (at least to laboratory rats) and that most animals (at least laboratory rats) are similar in their preferences for these solutions.

When Ss other than the white rat are used (e.g., calves, pigs, chickens and dogs) individual differences are frequently found which cast doubt on the generality of sugar preference (Kare, 1961; and Kare \& Ficken, 1963).

It was the purpose of this study to examine the sugar preferences of different rodent species and the basis for their preferences.

Method. Subjects were seven deer mice (Peromyscus leucopus), two Florida mice (Peromyscus floridanus) bred and reared at the Animal Behavior Laboratory at Michigan State University, and four Bannertail kangaroo rats (Dipodomys spectabilis) wild-trapped six months previously in Arizona. All Ss were housed individually with standard laboratory food always available and water available except during testing.

From April 3 to 26,1967 , all Ss were given choices of a $10 \%$ glucose solution and either a 5,10 , or $20 \%$ fructose solution for $2 \mathrm{~h}$ per day. Each glucose-fructose pair was presented five times on a random schedule with positions of glucose counterbalanced to inhibit the development of spatialposition preferences rather than preferences based on either sweetness or sugar. According to Cameron (1947) and others, a $10 \%$ glucose solution is sweeter than a $5 \%$ fructose solution, but relatively less sweet than either a 10 or $20 \%$ fructose solution.

Results. The average intakes of the sugar solutions, combined for the five trials, are presented in Table 1.

Even without statistical manipulation it is seen that, considering the species as homogeneous groups, deer mice prefer the sweeter glucose to $5 \%$ fructose, and perhaps the less-sweet glucose to $20 \%$ fructose. The Florida mice prefer the sweeter glucose to $5 \%$ fructose, perhaps the $10 \%$ fructose, and definitely prefer the $20 \%$ fructose to glucose. The kangaroo rats prefer $10 \%$ glucose to $5 \%$ fructose, and the sweeter $10 \%$ fructose to glucose.

If we examine the individual $S$, each was given 15 glucosefructose experiences, and if we require at least a $0.3 \mathrm{cc}$ difference in intake between the two solutions to be scored as a preference,

Table 1

Average Intake of Sugar Solutions in cc's Combined over Five Trials

$10 \%$ glucose- $\quad 10 \%$ glucose- $\quad 10 \%$ glucose$5 \%$ fructose $\quad 10 \%$ fructose $\quad 20 \%$ fructose

\section{P. leucopus}

(deer mice)

$1.25 \quad .30$

30

1.00

.90

85

.69

$(\mathrm{N}=7)$

P. floridanus

(Florida mice)

3.82

.66

2.28

2.71

1.16

$(\mathrm{N}=2)$

D. spectabilis

(Kangaroo rats)

$1.57 \quad .98$

.95

1.52

.58 then the preferences for sugar, side, or sweetness can be examined for the individual as well as the group.

It was found that four of the seven deer mice consistently chose glucose (at least $80 \%$ of their choices were glucose of the total 15 trials), two chose the sweeter solution, and one preferred whichever solution was on the left side. Both Florida mice chose the sweeter solution. Two kangaroo rats chose the sweeter solution, one exhibited a left preference, and the remaining S's preference was random.

The individual differences observed in the present study were not found in a recent study by Wagner (1968) using the same animals where the choices were glucose or water. In that study all Ss uniformly chose glucose. As noted earlier, Kare and coworkers have also noticed individual differences in preferences for sweets. They found that while most pigs accept and most dogs reject saccharin, some individuals have the opposite preferences, and that some, but not all, chickens like glucose, and some, but not all, calves prefer fructose. In most instances the choices were water vs sweetener. Few, if any, studies have reported on individual differences in the laboratory rat (Carpenter, 1958, in fact, precluded the possible examination of such individual differences by measuring the group consumption of sucrose by eight rats). It is possible that excessive inbreeding (Richter, 1959) and the relatively sterile laboratory environment have obscured or selected against individual differences at least as related to sugar preference. Perhaps the absence (Wagner, 1968) or presence (here) of individual differences can be explained on the basis of relative differences in incentive values (palatability) of the two choices. Young \& Falk (1956) report similar findings in acceptability of tap- or distilled-water in thirsty and nonthirsty rats, where they postulated that thirsty rats failed to discriminate because there was relatively less difference between the two choices. In this experiment both choices are sweet and perhaps there is relatively less difference between them than there would be between sugar and water. This would allow for the appearance of individual differences in preferential choice behavior based on factors other than sweetness. Whereas, with the sugar-water pair, the obvious differences between the choices ensures the sweetness-based preference, and all Ss prefer sugar. Wagner (1967) has also reported individual differences in the Ord kangaroo rat (Dipodomys ordii) when given choices of two glucose solutions of varying concentrations. Four of the recently wild-trapped Ss preferred the less-sweet solution, but one had a left-position preference.

In conclusion, these data suggest the need for further studies with different species examining sweet-sweet choices rather than water-sweet choices and observing individual differences rather than (a) obscuring these differences with grouped data, (b) omitting deviant Ss from the analysis, or (c) persisting in using the overworked, and perhaps atypical, laboratory rat.

\section{REFERENCES}

CAMERON, J. T. The taste sense and the relative sweetness of sugars. Sug. Res. Found., Sci. Rep., 1947, Ser., No. 9.

CARPENTER, J. A. A comparison of stimulus-presentation procedures in taste-preference experiments. J. comp. physiol. Psychol, 1958, 51, 561-564.

COLLIER, G., \& MYERS, L. The loci of reinforcement. J. exp. Psychol, $1961,61,57-66$.

KARE, M. R. Comparative aspects of taste. In M. R. Kare and B. P. Halpern (Eds.), The physiological and behavioral aspects of taste. Chicago: Univ. Chicago Press, 1961. Pp. 16-27.

KARE, M. R., \& FICKEN, M. S. Comparative studies on the sense of taste. In Y. Zotterman (Ed.), Olfaction and taste. New York: Pergamon, 1963. Pp. 285-297.

MARX, M. H., \& EDWARDS, D. C. Speed of reinforced running response following increasing and decreasing orders of sucrose concentration. J. exp. Psychol, 1966, 71, 160-161. 
RICHTER, C. P. Rats, man and the welfare state. Amer. Psychologist, 1959 , 14, 18-28.

WAGNER, M. W. Comparative sugar preference in grasshopper mice and kangaroo rats. J. Mammalogy, 1967, 48, 324-326.

WAGNER, M. W. Studies on comparative sugar preference in rodents. I: Methodology differences. Psychon. Sci., 1968, 11, ooo-ooo.

YOUNG, P. T. Hedonic organization and regulation of behavior. Psychol.
Rev., 1966, 73, 59-86.

YOUNG, P. T., \& FALK, J. L. The acceptability of tap water and distilled water to nonthirsty rats. J. comp. physiol. Psychol., 1956, 49, 336-338.

\section{NOTES}

1. This research was supported by NIH grant No. MH 10185 to M. W. Wagner. 2. Now at State University College, Oswego, N. Y. 13126. 